University for Business and Technology in Kosovo

UBT Knowledge Center

Oct 27th, 9:00 AM - 10:30 AM

\title{
"Circular Economy" as an Imperative Indicator of a Sustainable Urban Development Derived by Construction Industry - Case study Pristina
}

\author{
Binak Beqaj \\ University for Business and Technology, bbeqaj@ubt-uni.net \\ Blerta Vula Rizvanolli \\ University for Business and Technology, blerta.vula@ubt-uni.net
}

Follow this and additional works at: https://knowledgecenter.ubt-uni.net/conference

Part of the Architecture Commons

\section{Recommended Citation \\ Beqaj, Binak and Rizvanolli, Blerta Vula, "'Circular Economy" as an Imperative Indicator of a Sustainable Urban Development Derived by Construction Industry - Case study Pristina" (2018). UBT International Conference. 1. \\ https://knowledgecenter.ubt-uni.net/conference/2018/all-events/1}

This Event is brought to you for free and open access by the Publication and Journals at UBT Knowledge Center. It has been accepted for inclusion in UBT International Conference by an authorized administrator of UBT Knowledge Center. For more information, please contact knowledge.center@ubt-uni.net. 


\title{
"Circular Economy" as an Imperative Indicator of a Sustainable Urban Development Derived by Construction Industry - Case study Pristina
}

\author{
Binak Beqaj ${ }^{1}$, Blerta Vula Rizvanolli ${ }^{2}$ \\ UBT - Higher Education Institution, Lagjja Kalabria, 10000 p.n., Prishtine, \\ Kosovo \\ bbeqaj@ubt-uni.net ${ }^{1}$,blerta.vula@ubt-uni.net
}

\begin{abstract}
Construction field is an important industry for improving resource productivity and with impact on urban development and GDP of the Country (actually in Kosova, as calculated on the level of $15.76 \%$ ). The intention of the system promoted by the European Union as "Circular Economy" is to keep the added value of the products for as long as possible and virtually eliminate waste from urban spaces as a fundamental guide of urban sustainability. The process of turning waste into a resource of new modes seems to reshape the development of construction industries, especially now when the need for building materials is increasing focusing on the rapid growth of urban areas. The overall objective is to minimize the critical impact that the industry has in the urban environment such as: Waste Generating, Greenhouse, Gas Emission, Noise and Dust Generating. The six actions that rule the "Circular Economy" profoundly improves environmental benefits for urban area are:

- Regenerate

- Share

- Optimize

- Loop

- Virtualize and

- Exchange

Understanding the fundamental needs of Pristina (using qualitative and comparative methodology) to catch up with the actual European trends of sustainable economic development and sustainable urban development, trigger the question raised by this research to analyze the construction industry development vs. rapid urban growth in Pristina and give recommendations on feasible actions to comply with international standards of "Circular Economy".
\end{abstract}

Keywords: Circular Economy, construction, industry, waste, environment, sustainability, urban, area. 


\section{Introduction}

The actual urban development in Pristina and its rapid growth during the last 20 years indicates the fast enlargement of construction and real estate industry. The city population is expanded concentrating in the urban area along with the residential sector, which actually constitutes in the largest division of new constructed buildings.
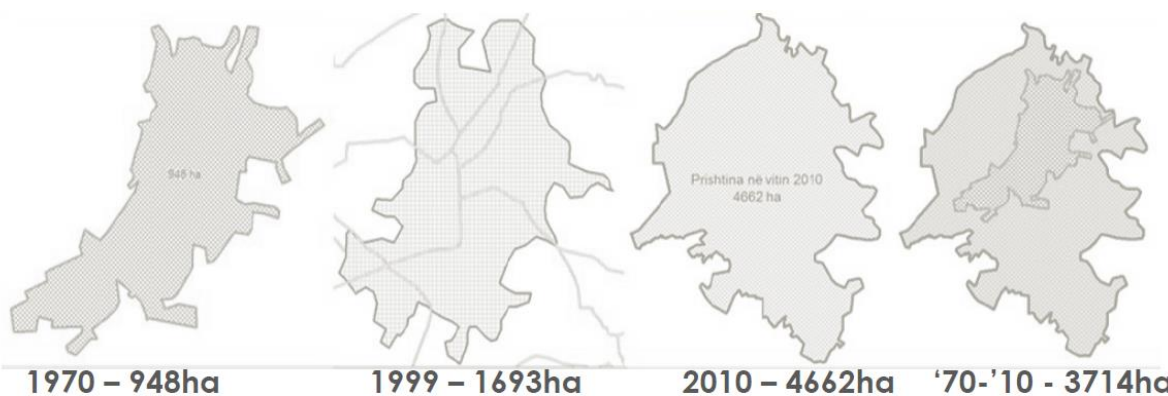

Fig.1_Expansion of Pristina Urban Area 1970-2010

The aim of this research is to analyze the challenges that pursue the construction and real estate industry, as two of the major contributors of country's GDP. Their implementation faces with the constant demand of raw materials which encounter for $25-40 \%$ of global carbon emissions. Only $20-30 \%$ of these materials are reused or recycled while $70-80 \%$ of them are discarded mainly consisting of bricks and concrete (80-83\%). In Kosovo the amount of waste generated from these sectors is $73 \mathrm{~kg} / \mathrm{inhabitant}$ on annual bases with the potential threat of increasing during the upcoming years while the recycling sector still remain very deficient.

The latest global answer to these challenges is proven to be the "Circular Economy" which looks forward to a more restorative and regenerative approach as an opportunity of establishing a system which aims to keep products, components, and materials in the construction loop for a longer time by turning the ones that are at the end of their service life into resources for new materials. This viewpoint would lead to more Energy Efficient cities and would impressively decrease carbon emission, while boosting the global economy. From the urban development perspective, this approach would result as a tool for policymakers as well as it would trigger businesses toward a Recycling and Re-usage of Building Materials.

The case study is based on the analysis of Waste Management in Kosovo on one side, indicating the level of construction and demolition waste materials, and the level of residential uninhabited buildings stock which is continuously increasing on daily basis reaching the level of 2.9 million $\mathrm{m}^{2}$ in 2016, only in urban area of Pristina. In reference to literature review and the data gathered through a qualitative approach, this paper triggers practical recommendations which encourage further examination of their useful implementation.

\section{Literature Review}

Circular Economy has been lately added in the professional vocabulary as an opportunity for future development in different industries even though it was initially initiated by European Commission 40 years ago as an attempt to substitute manpower with energy. As emphasized by 
Ellen McArthur (2017), the time for "Take, Make and Dispose" is now over and the world is looking forward to a more restorative and regenerative approach offered by Circular Economy as an opportunity of building an economic, natural and social capital which aims to keep products, components, and materials at their highest utility and value at all times.

A 'circular economy' would turn goods that are at the end of their service life into resources for others, closing loops in industrial ecosystems and minimizing waste. It replaces production with sufficiency: reuse what you can, recycle what cannot be reused, repair what is broken, remanufacture what cannot be repaired (Stahel, 2016).

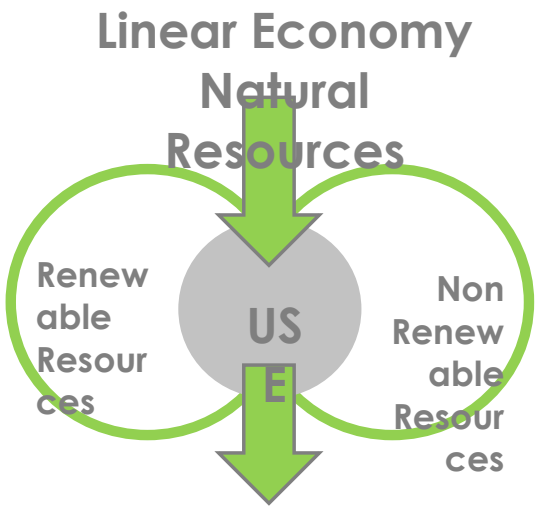

Landfill and

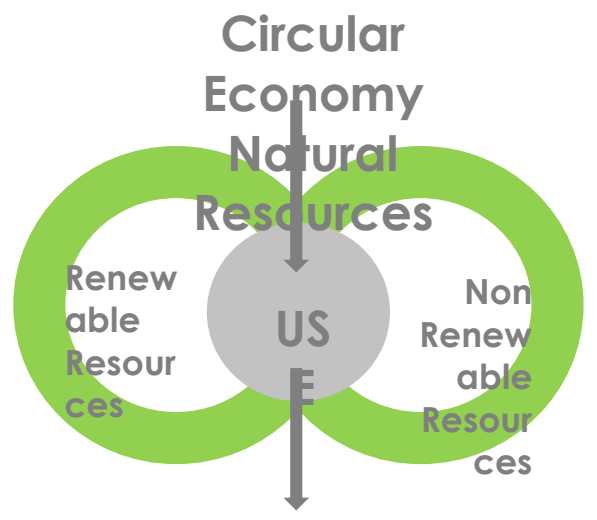

Landfill and

\section{TRANSITION TOWARD A CIRCULAR ECONOMY}

Fig.2_From Linear to a circular Economy

In our current, linear economy, approximately $80 \%$ of what we use is directly discarded after usage (Sempels and Hoffmann, 2013), even more over 99\% of the total material flow generated in order to produce different products ends up in waste disposal within 6 months (Hawken et al., 2013).

A recent study undertaken by Club of Rome in five European nations found out that a shift toward a Circular Economy by 2030, would insure economies of these countries to be $25 \%$ more Energy Efficient, would led to $50 \%$ reduction in carbon emission by using renewable sources in energy mix, and would extend to minimum $25 \%$ of material efficiency in manufacturing organizations (Wijkman and Skanberg, 2015). On the other hand, World Economic Forum, the Ellen MacArthur Foundation and McKinsey \& Company indicated that the transition to a circular economy would create an opportunity in excess of 1 trillion USD for the global economy (E. M. Foundation, 2014)

The transition to a circular economy is not an easy process and it requires changing of consumer habits and routines. Research and innovation are needed at all levels - social, technological and commercial. Economists and environmental along with material's scientists need to assess the ecological impacts and costs and benefits of products. An extensive effort is needed to convince businesses and governments that a circular economy is feasible. This transition entails four fundamental building blocks: Materials and Product Design; New Business Models; Global Reverse Networks; Enabling Conditions (Planing, 2015). 
MacArthur (2013) identified a set of six actions that businesses and governments can take in order to insure a smooth transition to a circular economy: Regenerate, Share, Optimise, Loop, Virtualise, and Exchange.

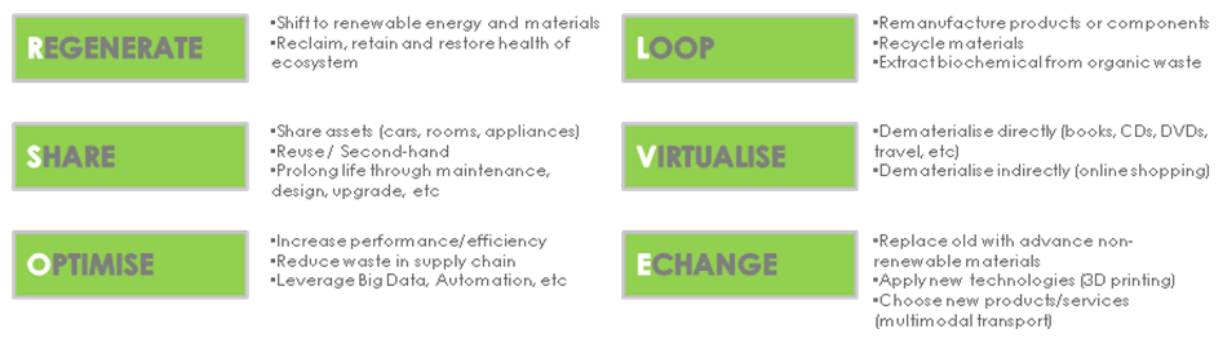

Fig.3_MCArthur's six actions toward a circular economy

Circular economy business models derive in two main groups: those that encourage reuse and repair, remanufacture, upgrades and retrofits as a prerequisite to extend service life; and those that turn old goods into as-new resources by recycling the materials (Stahel, 2016).

\section{Circular Economy in Construction Industry}

On the other hand, the construction industry's appetite for raw materials is vast; it is the world's largest consumer of them and accounts for $25-40 \%$ of global carbon emissions.

In the last two decades an increasing research effort has been devoted to the evaluation of the sustainability of the construction and demolition sector in urban systems, due to its huge environmental impact and generation of a large amount of waste materials (Bowea and Powell, 2016). The circular economy framework and its basic principles "Reduce, Reuse and Recycle" have been proposed for evaluating and addressing more effectively the construction and demolition waste materials (Esa et al., 2017) as well as suggesting appropriate policies, in so making Circular Economy a current political goal in many countries worldwide (Ghisellini et al., 2016).

Based on the actual customer's mindset, it takes more labour and fewer resources to refurbish buildings than to erect new ones. The principle is true for any stock or capital, from mobile phones to arable land and cultural heritage. Having said that, as an innovative economic and production model Circular Economy primarily implies a mind-set change that considers waste as potentially useful resources and not as a problem to manage and dispose of in landfills, as in the past linear economy.

In construction industry, waste is well managed by many companies in Europe and worldwide, but yet, a huge amount of recyclable/ reusable materials are disposed. According to MacArthur (2013) only $20-30 \%$ of the materials used in construction industry are reused or recycled while $70-80 \%$ are discarded. This waste consist of different types of materials in variable amounts, depending on several factors such as their sources (residential, commercial, industrial buildings, roads, bridges), size (low-rise, high-rise), the type and method of activity that is carried out (e.g. construction, renovation, repair, demolition/deconstruction) and the location of the development (Diyamandoglu and Fortuna 2015). 
In European countries, Construction and Demolition waste mainly consist of bricks and concrete (80-83\%), the rest (17-20\%) are packaging and structure support materials (such as plastics, wood, metal, paper and cardboard) as well as overburden, namely material coming from excavation sites (clay and rocks, asphalt) (La Marca 2010).

Obviously demolition projects generate a larger amount of waste that could be more than 10 times higher than construction projects (Duan et al. 2014).

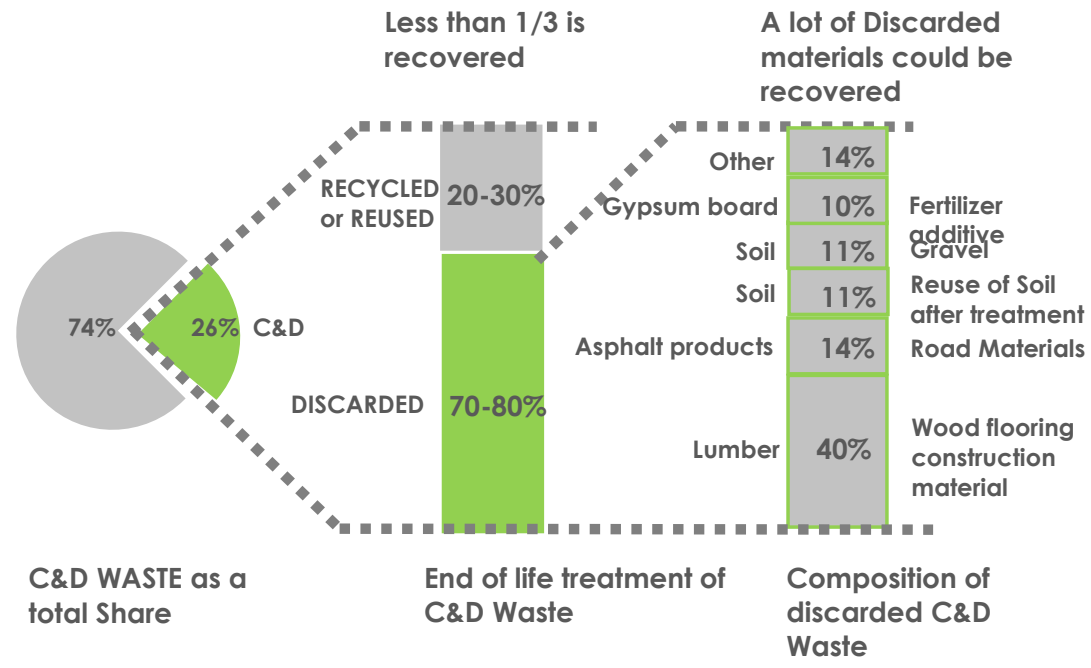

Fig.4_Waste materials in Construction and Demolition

Applying this principle to the construction industry could bring extremely cost-effective benefits. The World Economic Forum's report points out that by harnessing the capacity of the building sector, many countries could cut emission rates cost effectively and achieve energy savings of more than 30\%, according to the United Nations Environment Programme.

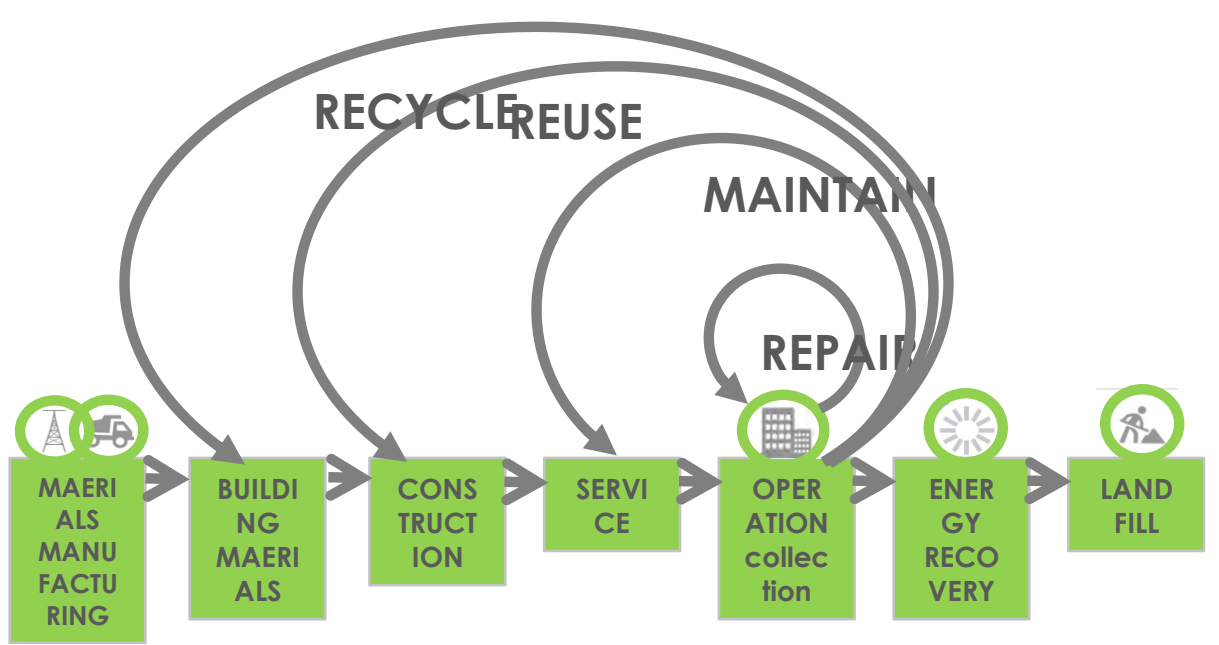

Fig.5_Circular Economy in Construction Value Chain 
From the urban development perspective, the Danish case study encourages delivering of the circular economy as "A toolkit for policymakers" (Egerton-Read, 2015). This study considers the policy and business opportunities in creating a construction that utilises industrialised production. Their proposal for government is: Re-Destination of Already Constructed Buildings Capacities where the sharing and multi-purposing of buildings is increased, while for businesses they promote Recycling and Re-usage of Building Materials.

\section{Construction Industry and Urban Development in Kosovo}

The meaning of urban area is structured by functionality of buildings and sites "Buildings are constructed and sites are developed in ways that are sensitively to both: historical and contemporary context." (LaGro Jr, 2013).

The general analyses of this research are based on systemic literature review related to people, buildings and public spaces, study cases and researches of public opinion related to the construction industry and urban development in Prishtina. City, is considered to be a rational modelling, plan and design which is used by citizens while it depends mostly from the quality of public policy defined as "Institutional, groups and networks, rational actors, ideas (John, 2013) which relies in the quality indicators such as:

Number of the constructed buildings in relation with community needs, considering how many of them are not in use;

Trend of building permits issued and illegal constructions trends considering how many of them can be repurposed;

Investments trends.

Taking in consideration the rapid urban development of Kosovo capital City, Pristina, especially during last two decades, positive and negative aspects may be highlighted. In concentration of business and their potential unstructured investment capacities, the major consequences noticed indicate: increased number of inhabitants, mass new constructions, mass demolishing of existing stock, transformation from individual to collective housing, low quality of constructions, disproportion between demand and supply curve related to the buildings, disproportion between needs and buying capacities, disproportion between use and not use of constructed buildings, etc.

In this regard, the importance of "Circular economy" in a sustainable urban development of the country's economy is unavoidable knowing that poor economy along with unplanned development concepts are characteristics of under development countries. In addition, study case of Prishtina shows that there is a huge stock of un-used newly constructed buildings, a massive destroy of existing buildings, lack of buildings and spatial multi-functionality usage, huge stock of construction and demolition garbage and environmental problems related to that. 


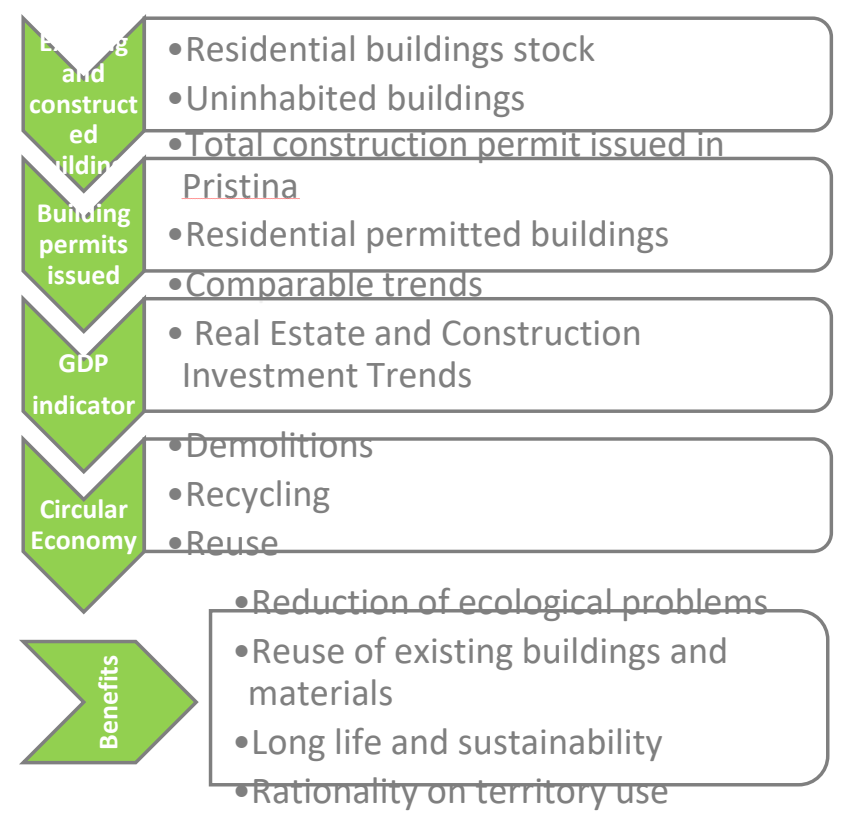

Fig.6. "Circular economy" and possible urban development benefit (source: research work, August 2017)

Based on the data gathered from Kosovo Agency of Statistics (KAS, 2017), Construction Industry, together with Food Industry and Minerals, is one of the sectors that produce most dangerous waste. Besides, within its territory, Kosovo is able to recycle only Metals $(75.6 \%)$, Paper (5.4\%), Plastics (8.0\%), Glass (0.01\%) and Textiles (0.8\%).

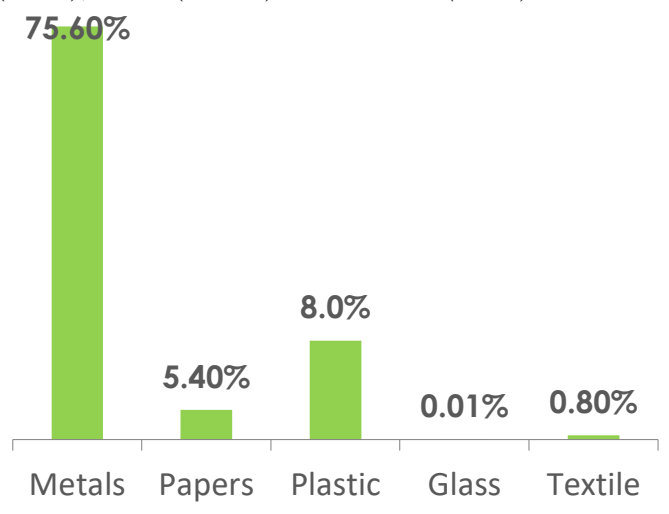

Fig.7. Waste recycling capacity in Kosovo

On the other hand, according to the Waste Management Strategy of Republic of Kosovo, developed in 2013 by the Ministry of Environment and Spatial Planning, on annual bases, Kosovo produces 167,900 ton waste from Buildings Construction and Demolition or $73 \mathrm{~kg} /$ inhabitant. This amount is expected to be increased dramatically, when demolition of Buildings of "Kosova 
A" power plant starts by 2018 . Even though, based in this strategy, it is foreseen that $80 \%$ of Construction and Demolition Waste shall be reused by 2022.

Moreover, in reference to the data published by Kosovo Agency of Statistics (2013), 24,1\% of the buildings in Urban Area of Kosovo are Uninhabited. While, only in the urban area of the capital city of Pristina, the uninhabited area reach the level of 2.4 million $\mathrm{m}^{2}$.

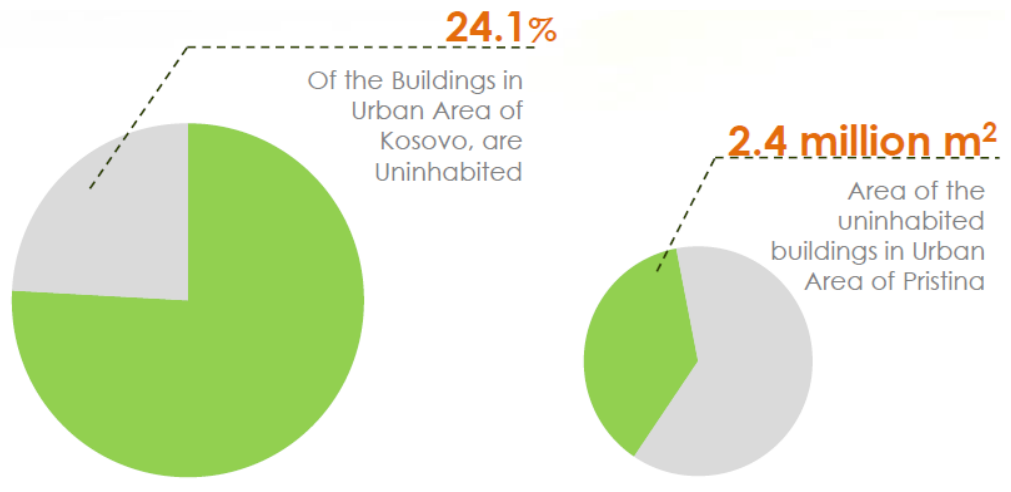

Fig.8. Uninhabited buildings in Kosovo and Pristina

Besides, the updated data published by Municipality of Pristina (2017) indicate that more than $80 \%$ of the total construction permits issued by this municipality during the years 2012-2016 relate to residential buildings.

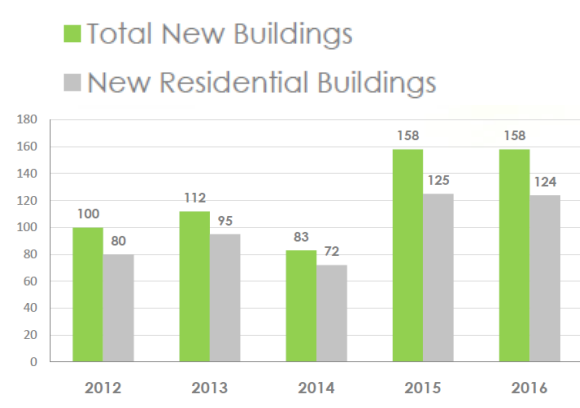

Fig.9. Number of construction permits issued by Pristina Municipality 2012-

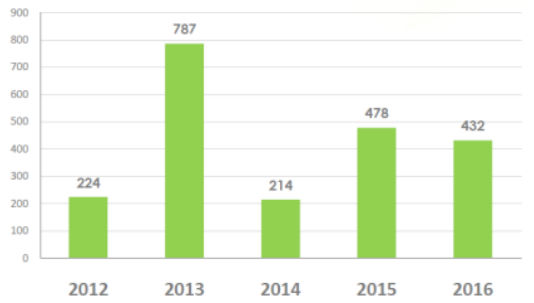

Fig.10. Total residential area permitted by Pristina Municipality 2012-2016

The total residential permitted areas in Pristina, reached the highest level of $787.000 \mathrm{~m}^{2}$ in 2013 and dropped to $432.000 \mathrm{~m}^{2}$ in 2016.

On the other hand, the investment trends, shows that Construction and Real Estate Industry remain among the most important sectors that in 2016 contributed with $8.3 \%$ and $10.2 \%$ in the country's GDP respectively. 


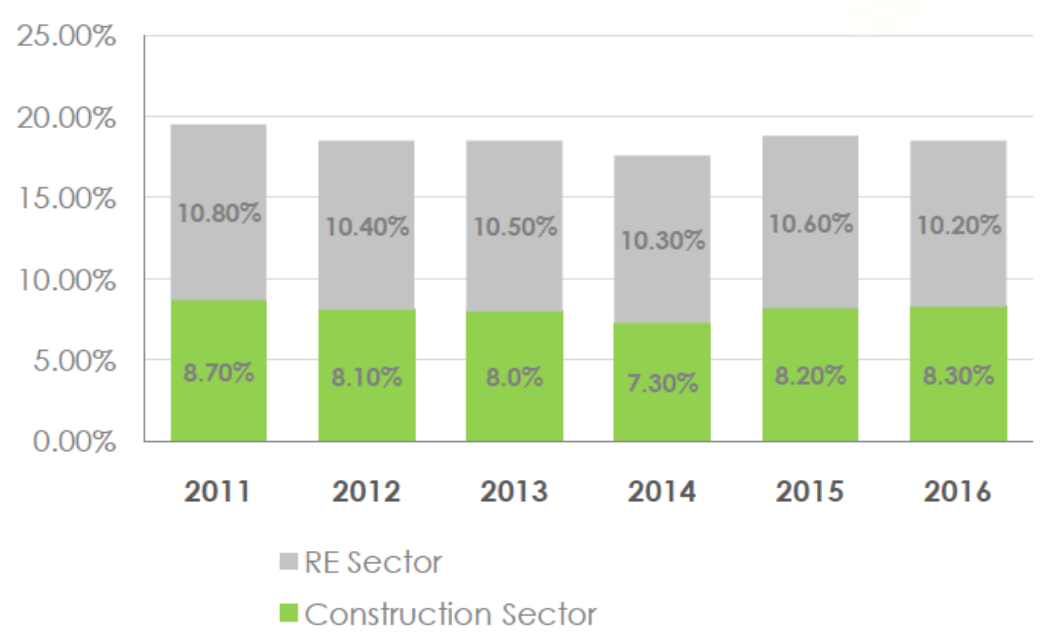

Fig.11. Contribution of Construction and Real Estate Sectors in Kosovo GDP 2011-2016

From the above presented data, it may be resumed that the Total Residential Area in Pristina up to 2011 was -9.8 million $\mathrm{m}^{2}$ and this amount is added by 2.135 million $\mathrm{m}^{2}$ for the years 2012 2016

If the previous trends of having $24.1 \%$ of uninhabited residential areas have continued, it means that by the end of 2016 there are 2.9 million $\mathrm{m}^{2}$ uninhabited residential areas in Pristina.

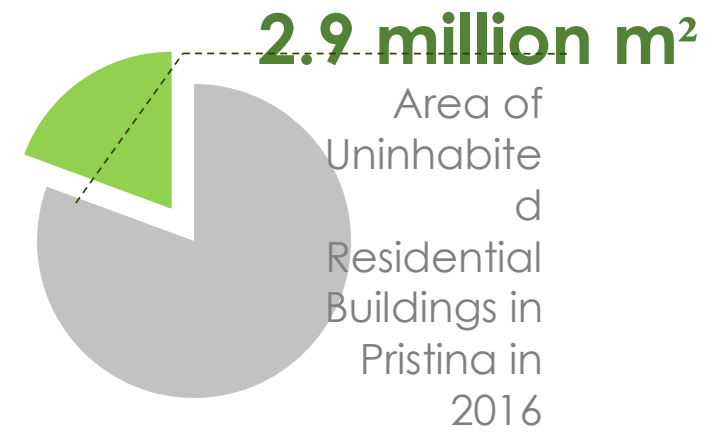

Fig.12. Uninhabited residential area in Pristina in 2016

\section{Conclusions}

The complex, dynamic, forever-changing construction industry has its own challenges that among others, relies in a massive amount of discarded raw materials which encounter to a huge environmental impact. The latest global reaction to this issue is the so-called "Circular Economy" which anticipates to a more sustainable approach as an opportunity of establishing a system which aims to keep products, components, and materials in the construction loop for a longer time by turning the ones that are at the end of their service life into resources for new materials. 
This paper aims to analyse the construction industry in Kosovo, and the implication of Circular Economy approach to the future urban development of Pristina city. Utilisation of the up-to-date literature along with data gathered for the particular case study, encourage boosting of Circular Economy approach in Construction Industry and as a result, facilitating Urban Development of Pristina, by promoting the following steps in both, business perspective and as a policy making tools:

Expand the range of recycling and reusing of construction and demolition waste, including also:

- $\quad$ Concrete / Rock / Brick Waste - as a gravel and erosion control material;

- $\quad$ Gypsum Board - as a fertilizer additive;

- $\quad$ Asphalt Products - as road building materials;

- $\quad$ Lumber - as wood flooring construction material

Re-Destination of constructed residential spare capacities by embracing the six actions approach Regenerate, Share, Optimise, Loop, Virtualise, and Exchange:

- Considering the 2.9 million $\mathrm{m}^{2}$ of uninhabited residential building in Pristina, the local government shall re-consider the regulations of issuing further permits, and aim to increase share and multi-purposing of space as a solution for slower urban area development, which will increase the capacities of the investment in actual infrastructure by reducing the need for building a new one.

From the undertaken research it may be derived that certain institutional and business term innovative modifications are required in Kosovo construction industry in order to enhance adoption of global trends of Circular Economy. This broad area of investigation, shall continuously motivate future researches who aim for sustainable restorative and regenerative solutions.

\section{References}

1. Bowea, M. D., \& Powell, J. C. 2016. "Developments in life cycle assessment applied to evaluate the environmental performance of construction and demolition wastes". Waste Management, 50, 151-172.

2. Diyamandoglu, V., \& Fortuna, L. M. 2015. "Deconstruction of wood-framed houses: Material recovery and environmental impact". Resources, Conservation and Recycling, 100, 21-30.

3. Duan, H., Wang, J., \& Huang, Q. 2015. "Encouraging the environmentally sound management of C\&D waste in China: An integrative review and research agenda". Renewable and Sustainable Energy Reviews, 43, 611-620.

4. E. M. Foundation. 2014. "The size of the prize," in A New Dynamic. Effective Business in a Circular Economy, 30-44

5. Egerton-Read . 2015. "Reimagining construction in Denmark: a $€ 1$ bn opportunity" . Accessed November 20, 2017.http://circulatenews.org/2015/12/reimagining-constructionin-denmark-a-elbn-opportunity/

6. Esa, M. R., Halog, A., \& Rigamonti, L. 2017. "Developing strategies for managing construction and demolition wastes in Malaysia based on the concept of circular economy”. Journal of Material Cycles and Waste Management, 19(3), 1144-1154. 
7. Ghisellini, P., Cialani, C., \& Ulgiati, S. 2016. "A review on circular economy: the expected transition to a balanced interplay of environmental and economic systems". Journal of Cleaner Production, 114, 11-32.

8. Hawken, P., Lovins, A. B., \& Lovins, L. H. 2013. Natural capitalism: The next industrial revolution. Routledge.

9. John, P. 2013. Analyzing public policy. Routledge

10. KAS. 2017. "Waste Data". Kosovo Agency of Statistics. Accessed November 20, 2017. http://ask.rks-gov.net/sq/agjencia-e-statistikave-te-kosoves/bujqesi/mbeturinat

11. La Marca, F. 2010. "Optimization of C\&D waste management by the application of life cycle Assessment (LCA) methodology: the case of the municipality of Rome, Italy". WIT Transactions on Ecology and the Environment, 129, 497-508.

12. LaGro, J.A., 2013. Site analysis: Informing context-sensitive and sustainable site planning and design. John Wiley \& Sons.

13. MacArthur, E. 2013. "Towards the Circular Economy, Economic and Business Rationale for an Accelerated Transition". Ellen MacArthur Foundation: Cowes, UK.

14. MacArthur, E. 2013. "Towards the circular economy". J. Ind. Ecol, 23-44.

15. McArthur.2017. "What is a circular economy?". Ellen MacArthur Foundation. Accessed November 20, 2017. https://www.ellenmacarthurfoundation.org/circular-economy

16. MESP. 2013. "Waste Management Strategy of Republic of Kosovo".Ministry of Environmnet and Spatial Planning. Accessed November 20, 2017. http://mmphrks.org/repository/docs/Strategiis\%C3\%AB_s\%C3\%AB_Republik\%C3\%ABs_s\%C3\%A B_Kosoves_per_Menaxhimin_e_Mbeturinave___alb._219608.pdf

17. Planing, P. 2015. "Business model innovation in a circular economy reasons for nonacceptance of circular business models". Open journal of business model innovation, 1 , 11 .

18. Sempels, C., \& Hoffmann, J. 2013. Sustainable innovation strategy: creating value in a world of finite resources. Springer.

19. Stahel, W. R. 2016. "Circular economy: a new relationship with our goods and materials would save resources and energy and create local jobs". Nature, 531(7595), 435-439.

20. Wijkman, A., \& Skanberg, K. 2015. "The circular economy and benefits for society". Jobs and climate clear winners in an economy based on renewable energy and resource efficiency. Rome. 